\title{
TEACHERS' PERCEIVED ATTITUDES TOWARD THE IMPLEMENTATION OF 21ST CENTURY SKILLS AT PRIMARY SCHOOL
}

\author{
Luh Putu Restu Adi Utami \\ English Language Education, Universitas Pendidikan Ganesha \\ e-mail: putu.restuadiutami@gmail.com \\ Ni Nyoman Padmadewi \\ English Language Education, Universitas Pendidikan Ganesha \\ e-mail: nym.padmadewi@undiksha.ac.id \\ Ni Luh Putu Eka Sulistia Dewi \\ English Language Education, Universitas Pendidikan Ganesha \\ e-mail: sulistia.dewi@undiksha.ac.id \\ Luh Putu Artini \\ English Language Education, Universitas Pendidikan Ganesha \\ e-mail: putu.artini@undiksha.ac.id
}

\begin{abstract}
21 st century education requires teachers to be able to understand the 21 st century skills and apply them in daily classroom practice. Although necessary for teachers, research on investigating the teachers' perceived attitudes toward the implementation of the $21 \mathrm{st}$ century skills for teaching English in primary schools in Bali is still limited. This study aimed to investigate primary school's English teachers' perceived attitudes toward the implementation of $21^{\text {st }}$-century skills. The design of this study was a sequential embedded mixed method with dominantly used qualitative design. This study used 3 English teachers and two headmasters from 2 primary schools in Tabanan regency as the subject. The data were collected by using a questionnaire and interview to gain the data of teachers' perceived attitudes toward the implementation of the $21^{\text {st }}$ century skills. From the data that have been obtained, primary English teachers gave positive attitudes toward $95,8 \%$ of the skills in the implementation of $21^{\text {st }}$ century skills. The interview section showed that the teacher lacks understanding of 21 st century skills because of a lack of in-depth information about 21 st century skills. Moreover, the teachers have to be aware of $21^{\text {st }}$ century skills in the assessment as one of the concepts that are adapted for Kurikulum 2013.
\end{abstract}

Keywords: $21^{\text {st }}$ century skills, teachers' perception, teachers' attitude

\section{INTRODUCTION}

The $21^{\text {st }}$ century is marked by a hundred years of transparency or globalization, which means that human culture underwent profound shifts in the $21^{\text {st }}$ century, which vary from the way of life in the previous century (Wijaya et al., 2016). It is said that the $21^{\text {st }}$ century is a century that asks for quality in all human endeavors and work. Naturally, the $21^{\text {st }}$ century demands quality human resources, which are produced by 
institutions that are professionally managed to produce superior results. These new demands require breakthroughs in thinking, drafting, and acting. In other words, a new paradigm is needed in dealing with new challenges (Wijaya et al., 2016).

Mukhadis (2013) stated that the 21st century is also known as the age of knowledge. In this era, all alternative efforts to meet the needs of life in various contexts are more knowledge-based. The main objective of 21 st-century learning is to build individual learning abilities and support their development into lifelong, active, independent learners; therefore, teachers need to become 'learning coaches' - a role that is very different from traditional classroom teachers. The 21 st century skills are the result of the demand from the era. There are four major frameworks of 21 st century skills, namely life and career skills, learning, and innovation skills, information, media, and technology skills, and the last is 21 st century themes (Trilling \& Fadel, 2009). Therefore, Bialik and Fadel (2015) state that knowledge is not enough for students in the industrial era. Kurikulum 2013 is the education system that is already implemented by the Indonesia government. The reason in implementing this curriculum, it is because of the preparation for the globalization in Indonesia (Padmadewi et al., 2018). Besides, Syamsuri and Ishaq (2010) state that Kurikulum 2013 adapts three concepts of 21st century educational concept. The first is 21 st century skills, scientific approach, and authentic assessment.

Teachers need to strengthen students' intellectual curiosity, their skills in identifying and solving problems, and their ability to build new knowledge with others. Zubaidah (2016) noted that teachers in the 21st century are not teachers who are proficient in every topic in the curriculum but must be experts in finding out together with their students, know how to do something, know how to know something or how to use something to do something new. An essential role of a 21 st-century teacher is their role as a role model for trust, openness, perseverance, and commitment for students in the face of uncertainty in the 21 st century.

Referring to the importance of teacher contributions and preparedness, it is necessary to examine teachers' attitudes towards the skills of the 21 st century, particularly in primary schools. The teacher's attitude towards 21 st-century skills is a crucial thing. It is because the knowledge is not enough if it is not followed by a positive attitude to implement them. If the teachers only understand the conceptual knowledge without showing a right (positive) attitude to apply it to their students, then the students will not have the skills of 21 st-century education. It will affect their life skills to live in the 21 st century era. There have been some researches conducted on the teachers' perceived attitude toward the implementation of 21st-century skills. However, the same research investigated for primary schools in teaching English as a foreign language for the Bali context is still limited.

\section{METHOD}

This study used a sequential embedded mixed method with dominant qualitative design. It was sequential because the data were obtained in order from the questionnaire, data analysis, and interview. Embedded mixed-method design involved the quantitative and qualitative data as the core data (Creswell, 2007). In this study, the core data was qualitative and supported by quantitative data from the questionnaire. The results of data analysis and interviews were described qualitatively, while the results from the questionnaire were calculated to determine the readiness of the teachers in inserting 21 st century skills in their assessment. 
The research took place in Tabanan regency. The study was conducted in two private primary schools. In both schools, English is taught for students from the first grade. English is taught for 4 hours each week as local content. The participants of the research were English teachers and headmasters. There were some reasons behind choosing them as the participants of this research. The headmasters were becoming the participants because they knew the program, implementation, and schools' conditionmeanwhile, the teachers as the facilitator of the teaching and learning process. There were five participants from both schools. They had a different background of education and experience in teaching. All of the English teachers were graduated from English Language Education and have the basic to teach English.

The was a questionnaire used to collect the data of teachers' attitudes toward the implementation of 21 st century skills. The questionnaire was based on 21 st century skills, which are contained three mains skills and supported by 21 st century themes based on Trilling and Fadel (2009). Those three dimensions had different indicators based on the skills in every dimension. An indicator developed into two items. Therefore there were 24 items in the questionnaire of teachers' readiness in inserting 21 st century skills in assessing their students' learning. Five items were developed from life and career skills. Four items were developed from learning and innovation skills. Three items were developed from information, media, and technology skills, and five items were developed from 21 st century themes. The respondents perceived their readiness on the insertion of those skills in their assessment for students in 4 scales. The scales were never (1), seldom (2), often (3), and always (4).

The questionnaire was distributed to all primary English teachers in those primary schools. In order to know how the teachers perceive their readiness in inserting $21 \mathrm{st}$ century skills in their assessment. The categorizations were decided through the Standard Deviation Ideal (SDi) and Mean Ideal (Mi) from the result of the respondents' score. The criteria can be seen in the table below.

Table 1. Categorization of Criteria

\begin{tabular}{lcc}
\multicolumn{1}{c}{ Criteria } & Interval & Categorizations \\
\hline$\overline{\mathrm{T}} \geq \mathrm{M}_{\mathrm{i}}+1,8 \mathrm{SD}_{\mathrm{i}}$ & $\overline{\mathrm{T}} \geq 59$ & Very Ready \\
\hline $\mathrm{M}_{\mathrm{i}}+0,6 \mathrm{SD}_{\mathrm{i}} \leq \overline{\mathrm{T}}<\mathrm{M}_{\mathrm{i}}+1,8 \mathrm{SD}_{\mathrm{i}}$ & $48 \leq \overline{\mathrm{T}}<59$ & Ready \\
\hline $\mathrm{M}_{\mathrm{i}}-0,6 \mathrm{SD}_{\mathrm{i}} \leq \overline{\mathrm{T}}<\mathrm{M}_{\mathrm{i}}+0,6 \mathrm{SD}_{\mathrm{i}}$ & $38 \leq \overline{\mathrm{T}}<48$ & Quite Ready \\
$\mathrm{M}_{\mathrm{i}}-1,8 \mathrm{SD}_{\mathrm{i}} \leq \overline{\mathrm{T}}<\mathrm{M}_{\mathrm{i}}-0,6 \mathrm{SD}_{\mathrm{i}}$ & $27 \leq \overline{\mathrm{T}}<38$ & Not Quite Ready \\
$\overline{\mathrm{T}}<\mathrm{M}_{\mathrm{i}}-1,8 \mathrm{SD}_{\mathrm{i}}$ & $\overline{\mathrm{T}}<27$ & Not Ready \\
\hline
\end{tabular}

The criteria were adopted from Candiasa (2010). Those criteria show the categorization in each dimension in the questionnaires. There were five criteria in the classification in deciding the level of teachers' attitudes.

The interview was done to reconfirm the information found in the questionnaire, and described qualitatively in the discussion. It used a semi-structured interview for the teachers in both schools. The interview was about teachers' knowledge in 21 st century skills, their implementation, and how they perceive their students in 21 st century skills. The interview was conducted after the questionnaire is distributed. 


\section{FINDING AND DISCUSSION}

In this study, it was found that the teachers had a $98,6 \%$ positive attitude toward the implementation of the skills. This result collected from the questionnaire result where $50,8 \%$ of respondents chose the "always" category, and the other $45 \%$ chose the "often" category. In the questionnaire, the skills were divided into four dimensions. They were life and career skills, learning and innovation skills, information, media and technology skills, and 21st century themes. Each dimension was described to see the teachers' responses about their attitude towards each dimension of 21 st century skills.

Table 2. English Teachers' Responses on Their Attitude in Implementing $21^{\text {st }}$ Century Skills

\begin{tabular}{|c|c|c|c|c|c|}
\hline \multirow{2}{*}{ No } & \multirow{2}{*}{ Statements } & \multicolumn{3}{|c|}{ Number of Respondent (\%) } & \multirow{2}{*}{$\begin{array}{l}\text { Total } \\
(\%)\end{array}$} \\
\hline & & 2 & 3 & 4 & \\
\hline \multicolumn{6}{|c|}{ Flexibility and Adaptability } \\
\hline 1 & $\begin{array}{l}\text { I am always ready and able to be flexible in } \\
\text { carrying out my duties as a teacher }\end{array}$ & & $2(40 \%)$ & $3(60 \%)$ & $\begin{array}{c}5 \\
(100 \%)\end{array}$ \\
\hline 2 & $\begin{array}{l}\text { I am always ready to adapt new aspects in } \\
\text { the educational field }\end{array}$ & & $3(60 \%)$ & $2(40 \%)$ & $\begin{array}{c}5 \\
(100 \%) \\
\end{array}$ \\
\hline \multicolumn{6}{|c|}{ Initiative and Self Direction } \\
\hline 3 & $\begin{array}{l}\text { I always have the initiative to improve the } \\
\text { ability of students inside and outside of the } \\
\text { classroom }\end{array}$ & & $2(40 \%)$ & $3(60 \%)$ & $\begin{array}{c}5 \\
(100 \%)\end{array}$ \\
\hline 4 & $\begin{array}{l}\text { I am able to control myself in every } \\
\text { situation of the learning process }\end{array}$ & & $2(40 \%)$ & $3(60 \%)$ & $\begin{array}{c}5 \\
(100 \%)\end{array}$ \\
\hline \multicolumn{6}{|c|}{ Social and Cross-cultural Skills } \\
\hline 5 & I socialize with all school's members & & $1(20 \%)$ & $4(80 \%)$ & $\begin{array}{c}5 \\
(100 \%)\end{array}$ \\
\hline 6 & I am able to work effectively in diversity & & $1(20 \%)$ & $4(80 \%)$ & $\begin{array}{c}5 \\
(100 \%) \\
\end{array}$ \\
\hline \multicolumn{6}{|c|}{ Productivity and Accountability } \\
\hline 7 & $\begin{array}{l}\text { I am able to produce a product from the } \\
\text { result of learning }\end{array}$ & $\begin{array}{c}1 \\
(20 \%) \\
\end{array}$ & $2(40 \%)$ & $2(40 \%)$ & $\begin{array}{c}5 \\
(100 \%) \\
\end{array}$ \\
\hline 8 & $\begin{array}{l}\text { I produce a high quality of teaching and } \\
\text { learning media or product }\end{array}$ & $\begin{array}{c}1 \\
(20 \%)\end{array}$ & $3(60 \%)$ & $1(20 \%)$ & $\begin{array}{c}5 \\
(100 \%)\end{array}$ \\
\hline \multicolumn{6}{|c|}{ Leadership and Responsibility } \\
\hline 9 & $\begin{array}{l}\text { I am able to show leadership in carrying out } \\
\text { my duties as a teacher }\end{array}$ & & $1(20 \%)$ & $4(80 \%)$ & $\begin{array}{c}5 \\
(100 \%) \\
\end{array}$ \\
\hline 10 & $\begin{array}{l}\text { I take responsibility in carrying out my } \\
\text { duties and public obligations }\end{array}$ & & & $\begin{array}{c}5 \\
(100 \%)\end{array}$ & $\begin{array}{c}5 \\
(100 \%)\end{array}$ \\
\hline \multicolumn{6}{|c|}{ Communication } \\
\hline 11 & $\begin{array}{l}\text { I am able to deliver materials through } \\
\text { verbal, written, and non-verbal } \\
\text { communication effectively }\end{array}$ & & $2(40 \%)$ & $3(60 \%)$ & $\begin{array}{c}5 \\
(100 \%)\end{array}$ \\
\hline 12 & $\begin{array}{l}\text { I am able to communicate well in order to } \\
\text { deliver learning goals, information, and } \\
\text { motivation to students }\end{array}$ & & $1(20 \%)$ & $4(80 \%)$ & $\begin{array}{c}5 \\
(100 \%)\end{array}$ \\
\hline
\end{tabular}




\begin{tabular}{|c|c|c|c|c|c|}
\hline \multirow{2}{*}{ No } & \multirow{2}{*}{ Statements } & \multicolumn{3}{|c|}{ Number of Respondent (\%) } & \multirow{2}{*}{$\begin{array}{l}\text { Total } \\
(\%)\end{array}$} \\
\hline & & 2 & 3 & 4 & \\
\hline \multicolumn{6}{|c|}{ Creativity and Innovation } \\
\hline 13 & $\begin{array}{l}\text { I am able to think creatively in using } \\
\text { teaching method to maximize teaching and } \\
\text { learning process }\end{array}$ & & $3(60 \%)$ & $2(40 \%)$ & $\begin{array}{c}5 \\
(100 \%)\end{array}$ \\
\hline 14 & $\begin{array}{l}\text { I contribute to creating Creativity and } \\
\text { Innovation ideas }\end{array}$ & $\begin{array}{c}1 \\
(20 \%)\end{array}$ & $3(60 \%)$ & $1(20 \%)$ & $\begin{array}{c}5 \\
(100 \%)\end{array}$ \\
\hline \multicolumn{6}{|c|}{ Critical Thinking and Problem Solving } \\
\hline 15 & $\begin{array}{l}\text { I am able to reflect my experiences in } \\
\text { teaching and learning process critically } \\
\text { from various points of view }\end{array}$ & $\begin{array}{c}1 \\
(20 \%)\end{array}$ & $2(40 \%)$ & $2(40 \%)$ & $\begin{array}{c}5 \\
(100 \%)\end{array}$ \\
\hline 16 & $\begin{array}{l}\text { I am able to solve the problem } \\
\text { conventionally or innovatively }\end{array}$ & & $3(60 \%)$ & $2(40 \%)$ & $\begin{array}{c}5 \\
(100 \%)\end{array}$ \\
\hline \multicolumn{6}{|c|}{ Collaboration } \\
\hline 17 & $\begin{array}{l}\text { I am able to work effectively and show } \\
\text { tolerance toward diversity in the group }\end{array}$ & & & $\begin{array}{c}5 \\
(100 \%)\end{array}$ & $\begin{array}{c}5 \\
(100 \%)\end{array}$ \\
\hline 18 & $\begin{array}{l}\text { I am able to work flexibly and compromise } \\
\text { to achieve common goals }\end{array}$ & & $1(20 \%)$ & $4(80 \%$ & $\begin{array}{c}5 \\
(100 \%) \\
\end{array}$ \\
\hline \multicolumn{6}{|c|}{ Information Literacy } \\
\hline 19 & $\begin{array}{l}\text { I am able to access information effectively } \\
\text { and efficiently }\end{array}$ & & $3(60 \%)$ & $2(40 \%)$ & $\begin{array}{c}5 \\
(100 \%)\end{array}$ \\
\hline 20 & $\begin{array}{l}\text { I utilize, manage, and apply information } \\
\text { accurately and creatively related to existing } \\
\text { issues and problems }\end{array}$ & & $4(80 \%)$ & $1(20 \%)$ & $\begin{array}{c}5 \\
(100 \%)\end{array}$ \\
\hline \multicolumn{6}{|c|}{ Media Literacy } \\
\hline 21 & $\begin{array}{l}\text { I understand why and how media is made } \\
\text { based on its purposes }\end{array}$ & & $4(80 \%)$ & $1(20 \%)$ & $\begin{array}{c}5 \\
(100 \%) \\
\end{array}$ \\
\hline 22 & $\begin{array}{l}\text { I am able to make and utilize media } \\
\text { effectively based on students' need }\end{array}$ & & $3(60 \%)$ & $2(40 \%)$ & $\begin{array}{c}5 \\
(100 \%)\end{array}$ \\
\hline \multicolumn{6}{|c|}{ Technology Literacy } \\
\hline 23 & $\begin{array}{l}\text { I am able to use technology as the tool for } \\
\text { arranging, researching, evaluating, and } \\
\text { communicating the information }\end{array}$ & & $\begin{array}{c}5 \\
(100 \%)\end{array}$ & & $\begin{array}{c}5 \\
(100 \%)\end{array}$ \\
\hline 24 & $\begin{array}{l}\text { I understand about legal issues around the } \\
\text { access and use of technology }\end{array}$ & $\begin{array}{c}1 \\
(20 \%)\end{array}$ & $3(60 \%)$ & $1(20 \%)$ & $\begin{array}{c}5 \\
(100 \%)\end{array}$ \\
\hline Tots & & $\begin{array}{c}5 \\
(4,2 \%)\end{array}$ & $\begin{array}{c}54 \\
(45 \%)\end{array}$ & $\begin{array}{c}61 \\
(50,8 \%)\end{array}$ & $\begin{array}{c}120 \\
(100 \%)\end{array}$ \\
\hline
\end{tabular}

\section{Life and Career Skills}

There are five skills in life and career skills. Most of the respondents gave positives attitudes toward the skills in life and career skills as $62 \%$ of them chose the always (4) category, and 34\% of them chose the often (3) category.

There were two statements in flexibility and adaptability. It was found that all of the respondents give a positive attitude towards flexibility and adaptability skills since they respond by often and always on the statements. Some of them perceived that their attitude was always flexible in carrying out their duties as a teacher and always ready in adapting new aspects in the educational field and the rest of them perceived that their attitude was often flexible in carrying out their duties as a teacher and often ready in adapting new aspects in the educational field. 
The third and fourth statements were based on initiative and self-direction in life and career skills. Both statements get the same response from the respondents. All of them gave a positive attitude toward the statements. $40 \%$ of the respondents perceived that they often have the initiative to improve students' ability and were able to control their selves in every situation of the learning process. In comparison, the other $60 \%$ of the respondents perceived that he always has the initiative to improve students' abilities and was able to control their selves in every situation of the learning process.

The next item is that social and cross-cultural skills consist of the fifth and the sixth statements. Both statements get the same response from the respondents, and all of them gave a positive attitude toward the statements. $20 \%$ of the respondents perceived that they often socialized with all school's members and worked effectively in diversity while the other $80 \%$ of the respondents perceived that they socialized with all school's members and worked effectively in variety.

The seventh and eighth item belongs to productivity and accountability. These statements gave respondents' perception of their attitude in producing a product from the result of learning and manufacturing high quality of teaching and learning media. In the seventh statement, the respondents have varied responses. All of them give different answers. There were $20 \%$ of them provide a negative response where they perceived that they were rarely able to control themselves in every situation of the learning process and produced a high quality of teaching and learning media.

The last item consists of the ninth and tenth items. These items had different responses from the respondents, but all of the responses were positive responses. In the ninth statement, the respondents mostly perceived that they always showed leadership in carrying out their duties. There was only one respondent perceived that he often showed leadership in carrying out their duties. While in the tenth item, all of the respondents perceived their attitude that they always took responsibility in personal and public responsibilities.

\section{Learning and Innovation Skills}

Learning and innovation skills or known as 4C skills, are the second dimension in the questionnaire of teachers' attitude in implementing the 21st century skills. Most of the respondents give positives attitudes toward the skills in life and career skills, as $57,5 \%$ of them chose the always (4) category, and 37,5\% of them decided the often (3) category.

In the eleventh and twelfth items, the respondents perceived their attitude in the communication skills in 21 st century education. These items obtained a different number of responses from the respondents, but all of them are positive responses. It was found that $40 \%$ of respondents perceived that they often delivered the material through verbal, written, and non-verbal communication excellently. In comparison, the other $60 \%$ of respondents perceived that they always did that. While in delivering learning goals and motivation for students, $20 \%$ of the respondents perceived that they often implemented that, and the other $80 \%$ of respondents perceived that they always applied that.

Creativity and innovation were the next items which consisted of the thirteenth and the fourteenth statement. The thirteenth statement is that the teachers can think creatively in using the teaching method. For this statement, the respondents give different positive responses. $60 \%$ of the respondents perceived that they were often able to think creatively in using teaching methods to maximize the teaching and learning 
process. While the other $40 \%$ of the respondents perceived that they are always able to do that. While the fourteenth statement is that it contributes to creating creativity and innovation, ideas gained a negative response from the respondents. It was found that $20 \%$ of the respondents perceived that they rarely contribute to creating creative and innovative ideas.

The next is critical thinking and problem-solving. The fifteenth and sixteenth statements were based on critical thinking and problem-solving. The fifteenth statement is about reflecting teachers' experiences in the teaching and learning process critically. The respondents gave different responses to these items. $20 \%$ of the respondents gave a negative response where they perceived that they rarely reflected teachers' experiences in the teaching and learning process critically. Meanwhile, in the sixteenth item, which is about solving problems, only gained two kinds of responses where $60 \%$ of them choose the often (3) category in implementing this statement.

The last two statements belong to collaboration skills. The respondents gave the same number of responses toward the seventeenth statement. All of the respondents $(100 \%)$ respondents perceived that they always worked effectively and tolerance in diversity. While in the eighteenth statement, $80 \%$ of the respondents perceived that they always worked flexibly and compromised to achieve the goals, and the other $20 \%$ of the respondents perceived that they often do that.

\section{Information, Media and Technology Skills}

Information, media, and technology skills are the third dimensions in the questionnaire. There are three skills in this dimension. They are information literacy, media literacy, and technology literacy. In this dimension, most of the respondents give positives attitudes toward the skills in life and career skills, as $73,3 \%$ of them chose the often (3) category, and $23,3 \%$ chose the always (4) category.

The nineteenth and twentieth statements based on information literacy. All of the respondents give positive responses to these statements in the questionnaire. Some of them perceived that they often access information effectively and also managing information accurately, and the rest of them perceived that they always do that.

The twenty-first statement is about understanding the purpose of media, and the twenty-second is about utilizing media effectively based on needs. These statements belonged to media literacy. In these two statements, all of the respondents gave positive responses. $80 \%$ of them perceived that they often understand media purposes and utilize media effectively based on students' needs. At the same time, the rest of them perceived that they always understand that.

The last two statements based on technology literacy. Both of these statements gained positive responses from the respondents. Most of the respondents perceived that they often use technology as the tool for arranging, researching, evaluating, and communicating the information and understand legal issues around the access and use of technology. Nevertheless, there was one respondent perceived that they always understand about legal issues around the access and use of technology.

Based on the findings above, the respondents gave positive responses toward their attitude of the 21st century skills based on the questionnaire. The score of primary English teachers on their responses in inserting 21st century skills in the assessment was 83,2 . The score was in the interval $\bar{T} \geq 82$ which means that the English teachers were very confident with their attitude toward the 21 st century skills 
The attitude of teachers towards the implementation of 21st century skills was being investigated. As mentioned in by Krebs and Schmidt (1993), attitude is an individual's tendency to react with a certain level of liking or disliking for an object, behavior, person, institution, or event - or other discriminatory aspects of the individual world. From this definition, it can be said that attitude is a person's positive and negative response to something.

The results of primary schools' English teachers in their attitude toward $21 \mathrm{st}$ century skills show that the teachers gave positive and negative responses. The result of this study is relevant to the calculation result by using a categorization level by Candiasa (2010) that showed the level of teachers' attitude was high, and it means that they are very confident with their attitude in implementing 21 st-century education.

Pratiwi (2018) states that teaching and learning is a process to develop new skills of students and change their attitudes for the better in a certain period. Because teachers teach 21 st-century students, they must also apply 21 st-century education to create a generation with distinctive and independent personalities and be able to improve the quality of national education. This result is supported by the study from Msila (2015) about teachers' readiness to use I.C.T. in the classroom. Msila (2015) stated that the attitudes of teachers are crucial in any advancement for teachers who do not have the right attitude are unable to incorporate curriculum changes effectively. Even when teachers are competent in innovation, they might not be successful in their classrooms when their attitudes are not positive. Syamsuri and Ishaq (2010) also support that today's teachers have to understand about 21 st century education to reach the goals in 21st century learning.

According to McDonald (2011), teachers' positive attitude in the implementation of education for the 21 st century is determined by their positive perspective on education for the 21 st century. The definition of perception refers to perception as to how someone views things based on socio-cultural elements. In this case, the views of the teachers were derived from a questionnaire consisting of skills and themes of $21 \mathrm{st}$ century education. When compared with the other theory of perception, relevant results were found. Data collection from teacher attitudes towards 21 st century educational skills is related to the arguments of Pecher and Zwaan (2005) about positive and negative perceptions. That was proven by all respondents giving their positive and negative perceptions on the implementation of 21 st century education.

Based on the results of the questionnaire on teacher attitudes towards 21 st century education, it was found positive and negative attitudes given by teachers. In addition to the teacher's attitude towards the application of 21 st century skills, a teacher gives his opinion about his attitude towards the application of 21 st century education. The teacher said that most of the 21st century skills had been applied in teaching and learning. But there are some skills that are less known about how to integrate them into English learning. The results of the interview make a stronger indication that in addition to positive attitudes, teachers also have a negative attitude towards the application of $21 \mathrm{st}$ century skills. That negative attitude arises because of the limited teacher understanding about $21^{\text {st }}$ century skills.

The attitude of teachers towards the application of 21 st century educational skills is influenced by their character. As stated by Li (2018), when a character shows a person as a person, that attitude tells the reason why the person is that type of person. Related to the argument of Li (2018), when this study is compared with the theory by Ponmozhi, 2017) about the characteristics of teachers in the 21 st century, it shows 
relevance. Ponmozhi (2017) mentioned eight characteristics of teachers in the $21 \mathrm{st}$ century, namely, adaptor, visionary, collaborator, risk-taker, learner, communicator, model, and leader.

When this study is compared with previous studies that have been done before, they found similarities and differences. Jan (2017) conducted research on the characteristics and development of teachers in the 21st century. There are 14 characteristics of teachers in the 21 st century, namely; student-centered classes and personalized instruction, students as producers, project-based learning, learning new technology, going global, being smart and using smartphones, blogs, digital go, collaborating, using Twitter chat, connecting, building positive digital footprints, innovate, and keep learning. Thus, he found that being able to use technology effectively to improve the teaching process was the most needed characteristic that must be possessed by teachers.

Besides, a study of smart social networking in 21 st century education has been carried out by Boholano (2017). He found that smart social networking requires critical thinking skills and the ability to integrate and evaluate real-world scenarios and authentic learning in teaching and learning. When this study was compared with the latest study, he found similarities and differences. While the ability to use technology was stated to be necessary, the teachers showed a positive attitude, as stated in the interview section. As they mentioned that the school had facilitated them with technology that can be used to support their teaching and learning process.

\section{CONCLUSION AND SUGGESTION}

Based on the objective of the study, findings, and discussion, it can be concluded that the English teachers in primary school have a positive and negative attitude toward the skills in the $21^{\text {st }}$ century skills. The English teachers were very confident to perceive that they have implemented most of the skills in the $21^{\text {st }}$ century skills to their students properly. However, it was found that the teachers did not get enough information about the $21^{\text {st }}$ century skills so that there were some misconceptions in their understanding of some of the skills in the $21^{\text {st }}$ century skills.

\section{REFERENCES}

Bialik, M., \& Fadel, C. (2015). Skills for the 21 st century : What should students learn? Center for Curriculum Redesign, 1(1), 4-9.

Boholano, H. B. (2017). Smart social networking: 21 century teaching. Research Pedagogy, 7(1), 21-29. https://doi.org/10.17810/2015.45

Candiasa, I. (2010). Statistik Univariat dan Bivariat disertai aplikasi SPSS. Unit Penerbitan Universitas Pendidikan Ganesha.

Creswell, J. W. (2007). An Introduction to Mixed Methods Office of Qualitative and Mixed Methods Research.

Jan, H. (2017). Teacher of 21 st Century: Characteristics and development teacher of 21 st century: Characteristics and Development. Research on Humanities and Social Sciences, 7(9), 50-54.

Krebs, D., \& Schmidt, P. (1993). New directions in attitude measurement. 
Li, T. (2018). What's the difference between attitude and character? Quora. https://www.quora.com/Whats-the-difference-between-attitude-and-chacacter

McDonald, S. M. (2011). Perception: A Concept Analysis. International Journal of Nursing Terminologies and Classification, 1-18.

Msila, V. (2015). Teacher Readiness and Information and Communications Technology ( ICT ) Use in Classrooms: A South African Case Study. Creative Education, 6(18), 1973-1981.

Mukhadis, A. (2013). Sosok manusia indonesia unggul dan berkarakter dalam bidang teknologi sebagai tuntutan hidup di era globalisasi. Jurnal Pendidikan Karakter, 2(2).

Padmadewi, N. N., Artini, L., \& Putu Kerti Nitiasih, P. (2018). Techniques for Building Character and Literacy for 21 st Century Education. 1st International Conference on Education Innovation (I.C.E.I. 2017, May. https://doi.org/10.2991/icei17.2018 .65

Pecher, D., \& Zwaan, R. A. (2005). Introduction to grounding cognition. Grounding Cognition: The Role of Perception and Action in Memory, Language, and Thinking, 1-7.

Ponmozhi, D. (2017). 21st century teaching competency of student teachers. Scholarly Research Journal for Interdisciplinary Studies, 4(35), 5945-5952.

Pratiwi, A. (2018). Literature Review: Mengembangkan Skill Pembelajaran Dalam Menyongsong Pendidikan Abad 21.

Syamsuri, A. S., \& Ishaq. (2010). Guru, generasi z, dan pembelajaran abad 21.

Trilling, B., \& Fadel, C. (2009). 21st century skills: Learning for life in our times.

Wijaya, E. Y., Sudjimat, D. A., \& Nyoto, A. (2016). Transformasi Pendidikan Abad 21 Sebagai Tuntutan Pengembangan Sumber Daya Manusia di Era Globalisasi. Prosiding Seminar Nasional Pendidikan Matematika 2016, 1, 263-278.

Zubaidah, S. (2016). Keterampilan abad ke-21 : keterampilan yang diajarkan. Seminar Nasional Pendidikan Dengan Tema "Isu-Isu Strategis Pembelajaran MIPA Abad 21, 21(10), 1-17. 